\title{
LABORATORY STUDIES ON THE ALLELOPATHIC ACTIVITY OF THE GREEN ALGA, SCENEDESMUS ACUMINATUS CRUDE EXTRACTS AGAINST THE GREEN ALGA CHLORELLA VULGARIS.
}

\author{
Dawah, A. M $^{1}$; Metwaly, M.R ${ }^{2}$; Nagdy, Z.A. ${ }^{1}$; Shaker, I.M $^{1}$. and \\ Mohmed, A.A ${ }^{1}$ \\ ${ }^{1}$ Limnology Dept., Central Lab for Aquaculture Research (CLAR), Abbassa \\ Agriculture Research Center, Egypt. \\ ${ }^{2}$ Department of Botany, Faculty of Science, Benha University.
}

\begin{abstract}
The allelopathic activity of the green alga named Scenedesmus acuminatus against the green alga Chlorella vulgaris has been reported. Two algae were isolated, purified and identified from water of earthen fish ponds of Central Laboratory for Aquaculture Research, Abbassa, Sharkia, Egypt. S. acuminatus was cultured in mass culture. Algal mass was harvested at exponential growth phase and dried then extracted by the organic solvents (ethanol or methanol) using a soxhlet apparatus. Allelopathic activity of the crude extracts was investigated with agar-well diffusion and paper-disc assay to demonstrate efficiency of antialgal principles against $C$. vulgaris. Findings revealed that two crude extracts had an inhibitory effect against $C$. vulgaris where, large and small inhibition zone caused by Agar-well diffusion assay. Ethanolic crude extract was 23.6 and $51.6 \mathrm{~mm}$ at concentrations of 100 and $400 \mu 1$ respectively. The largest and smallest clear zone caused by methanolic crude extract was 36.6 and $20 \mathrm{~mm}$ in favor of the above mention concentrations. On the other hand, the largest and smallest clear zone caused by paper- disc assay for ethanolic crude extract was 26.3 and $17.6 \mathrm{~mm}$ and for methanolic crude extract was 15.3 and $24 \mathrm{~mm}$ at concentrations of 10 and $40 \mu \mathrm{l}$ respectively. Keywords: Allelopathy, C. vulgaris, Crude extract. S. acuminatus.
\end{abstract}

\section{Introduction}

Algae are important component of aquatic ecosystems. They form the oxygen necessary to consumer organisms. Microalgae are commonly used in the rearing of marine fish larvae they are either added directly to water in the rearing tanks (Reitan et al., 1997) or as food for rotifers.

Releasing chemicals and/or toxins by plants or microorganisms that affect their potential competitors for resources is known as allelopathy (Lampert and Sommer, 1997). Allelopathy is considered as an important process that occurs among all groups of marine and freshwater primary producers (Gross, 2003 and Legrand et al. 2003). Allelochemicals (natural plant toxins) are considered promising sources of herbicides (including algaecides). Due to their natural origin, many researchers have suggested that most allelopathic compounds will not only be biodegradable but also less polluting than traditional herbicides 
(Macias et al., 1998) which means that most allelochemicals have short half lives compared to synthetic pesticides. It is difficult to isolate the bioactive compounds from phytoplankton due to its production in very small amounts. Under stress condition e.g., nutrient limitation; production of a highly active compound at low concentrations is a cost-effective strategy (Leflaive and Ten-Hage, 2007).

Allelopathic activity of green alga $S$. acuminatus crude extracts on growth of $C$. vulgaris was the specific objectives of this study.

\section{Materials and Methods}

Green algae S. acuminatus and C. vulgaris were isolated from Abbassa fish water ponds. Both species ware purified, identified and cultured in Bold'sBasal Medium BB.Medium (Bischoff and Bold, 1963) at pH 6.6.

\section{Mass culture of green algae:-}

Algal culture was obtained by cultivating of the green algae in $250 \mathrm{ml}$ Erlenmeyer flasks, each contain $150 \mathrm{ml}$ of the medium. Cultured flasks were stoppered with cotton plugs and sterilized in autoclave at $121.5^{\circ} \mathrm{C}$ and $1.5 \mathrm{~atm}$. for 20 minutes, after cooling they were inoculated with $30 \mathrm{ml}$ of the pre-culture of the green algae. The algal cultured was mentioned at $22 \pm 2^{\circ} \mathrm{C}$ and illuminated by florescent tubes with light intensity between 3000-5000 lux and a photoperiods of $19 / 5 \mathrm{~h}$, light /dark cycles. Cultured flasks were shaken three times daily to prevent wall growth.

One more Erlenmeyer flask containing $500 \mathrm{ml}$ of the BBM medium was inoculated by $100 \mathrm{ml}$ of pre-culture green algae. This process was repeated having $1500 \mathrm{ml}$ from pre-culture enough to inoculate the carboy.

\section{Harvesting, extraction and processing the algal biomass:-}

After 6 days algae reaching maximum growth, the circulation provided by the pumping system was stopped and the primary separation of the algal cells from the liquid phase was achieved by gravity separation forming thick sediment at the bottom of the carboy within $24 \mathrm{hrs}$. Supernatant was centrifuged at 2500 rpm for 20 minutes. The algal slurry obtained as thick sediment and by centrifugation was dried in an oven at $50^{\circ} \mathrm{C}$ for $24 \mathrm{hr}$.

Dried algal biomass appeared in the form of small pellets were blended in an electric coffee mill. Resulting powder was submitted to lipid-soluble extraction with ethanol or methanol $(95 \%) 1: 15(\mathrm{~W}: \mathrm{V})$ using a soxhlet extractor at $55-60^{\circ} \mathrm{C}$, all samples were refluxed until saturation $(24 \mathrm{hrs})$ and the respective extracts were dried in an oven at $50^{\circ} \mathrm{C}$.

Screening of crude extract of $S$. acuminatus against $C$. vulgaris:-

\section{(A)-Agar-well diffusion assay:-}

Agar plate well-diffusion method was used as described by (Desta, 2005). Sterilized Bold's-Basal agar Medium poured in sterilized Petri Dishes. After 
solidification, wells were cut from the plate using a sterile test tube (a sterile cork borer). A known volume of algal extract was introduced into each well and dried in room temperature. After drying, the plates were inoculated with $2 \mathrm{ml}$ of the fresh (target) $\log$ phase growing organism and evenly distributed using a sterile glass spreader. Plates were incubated at $22 \pm 2{ }^{\circ} \mathrm{C}$ for a week in phytoplankton lab. Inhibition zones were measured with a ruler and compared with control well (well containing only the respective solvent). Experiment was carried out in triplicate.

\section{(B)-Paper disk assay:}

Sterilized Bold's-Basal agar Medium poured in sterilized Petri Dishes. After solidification; the plates were inoculated with $2 \mathrm{ml}$ of the fresh (target) log phase growing organism evenly distributed using a sterile glass spreader. The empty sterile paper discs were dipped in the respective extracts and air-dried in the room temperature and placed on the agar medium using sterilized forceps (Bauer et al., 1966). The plates were incubated at $22 \pm 2{ }^{\circ} \mathrm{C}$ for a week in phytoplankton lab. Allelopathic activity was measured as mentioned above. Control discs soaked with respective solvents were run simultaneously. Disk diffusion assay was carried out in triplicate.

Allelopathic activity on growth inhibition was estimated by percentage of inhibition (PI), which is calculated by the following equation:-

Percentage of inhibition PI $(\%)=$ diameter of inhibition zone/diameter of growth $\times 100$.

\section{Considering that:-}

Control inhibitor concentration $=$ zero.

Diameter of growth $=90 \mathrm{~mm}$.

\section{Statistical analysis}

Statistical analysis was performed using the analysis of variance (ANOVA) and Duncan's Multiple Test to determine differences among treatment means at significance level of 0.05. Standard errors were estimated. All statistics were run on the computer using the SAS program (SAS, 2010).

\section{Results}

Green algae which isolated from Abbassa fish ponds were identified as Scenedesmus acuminatus and Chlorella vulgaris. S. acuminatus is a small, non motile colonial green alga consisting of cells aligned in a flat plate. The cells are usually cylindrical but may be more lunate, ovoid or fusiform. Each cell contains a single parietal, plate-like chloroplast with a single pyrenoid.

C. vulgaris is a species of single-celled green algae; it is spherical shape, about 2 to $10 \mu \mathrm{m}$ in diameter, without flagella. Each cell has a bell-shape or cup shape parietal chloroplast with or without apyrenoid. 


\section{a- Agar- well diffusion assay:-}

Diameters of inhibition zones due to ethanolic extract of $S$. acuminatus at concentrations of 100,150,200, 250, 300 and $400 \mu 1$ were 23.3, 25.3, 30, 32.6, 42.6 and $51.6 \mathrm{~mm}$, respectively. On the other hand, diameters of inhibition zones due to methanolic extract of $S$. acuminatus at concentrations of 100, 150, 200, 250, 300 and $400 \mu 1$ were 20,23, 23, 23.3, 33.3 and $36.6 \mathrm{~mm}$, respectively. No clearing zones were noticed for control (respective organic solvents only).

The highest PI for ethanolic and methanolic extract was 57.4 and 40.66 $\%$, respectively at concentration of $400 \mu \mathrm{l}$ for each extract, while the lowest PI for ethanolic and methanolic extract was 26.22 and $22.2 \%$, respectively at concentration of $100 \mu \mathrm{l}$ for each extract. Results were shown in Table 1 and photo, $1,2,3$ and 4 .

Table (1): Allelopathic activity of ethanolic or methanolic crude extract of Scenedesmus acuminatus against Chlorella vulgaris growth by (Agar-well diffusion assay)

\begin{tabular}{|c|c|c|}
\hline \multirow{2}{*}{$\begin{array}{c}\text { Quantity of algal extract } \\
(\mu \mathrm{l}) .\end{array}$} & \multicolumn{2}{|c|}{ Diameter of inhibition zone $(\mathrm{mm})$} \\
\cline { 2 - 3 } & Methanolic extract & Ethanolic extract \\
\hline 100 & $23.6 \pm 1.3 \mathrm{a}$ & $20 \pm 0.57 \mathrm{a}$ \\
\hline 150 & $25.3 \pm 0.88 \mathrm{a}$ & $23 \pm 0.57 \mathrm{a}$ \\
\hline 200 & $30 \pm 0.57 \mathrm{a}$ & $23 \pm 0.57 \mathrm{~b}$ \\
\hline 250 & $32.6 \pm 0.3 \mathrm{a}$ & $23.3 \pm 1.8 \mathrm{~b}$ \\
\hline 300 & $42.6 \pm 0.3 \mathrm{a}$ & $33.3 \pm 3.3 \mathrm{a}$ \\
\hline 400 & $51.6 \pm 2.9 \mathrm{a}$ & $36.6 \pm 3.3 \mathrm{~b}$ \\
\hline
\end{tabular}

* letters $\mathrm{a}$ and $\mathrm{b}$ show that there's significant difference between ethanolic and methanolic extract at each treatment in the same raw, while data shown with the same letters aren't significantly different at $\mathrm{P}<0.05$.

\section{b- Paper- disc assay:-}

Diameters of inhibition zones due to ethanolic extract at concentrations $10,15,20,25,30,35$ and $40 \mu 1$ were 17.6, 18, 22, 22.3, 23.3, 25.3 and $26.3 \mathrm{~mm}$, respectively. On the other hand, diameters of inhibition zones due to methanolic extract at concentrations $10,15,20,25,30,35$ and $40 \mu 1$ were 15.3, 16, 19, 20, 21.3, 22.6 and $24 \mathrm{~mm}$ respectively. No clearing zones were noticed for control.

The highest PI for ethanolic and methanolic extract was 29.2 and $26.6 \%$ respectively at concentration of $40 \mu 1$ for each extract, while the lowest PI was 19.5 and $17 \%$ for ethanolic and methanolic extract respectively at concentration of $10 \mu \mathrm{l}$. The results were shown in Table 2 and photos, 5, 6, 7 and 8. No clearing zone noticed in control prepared for each charge of bioassay.

Egyptian J. of Phycol. Vol. 12, $2011 \quad$ - 50 - 


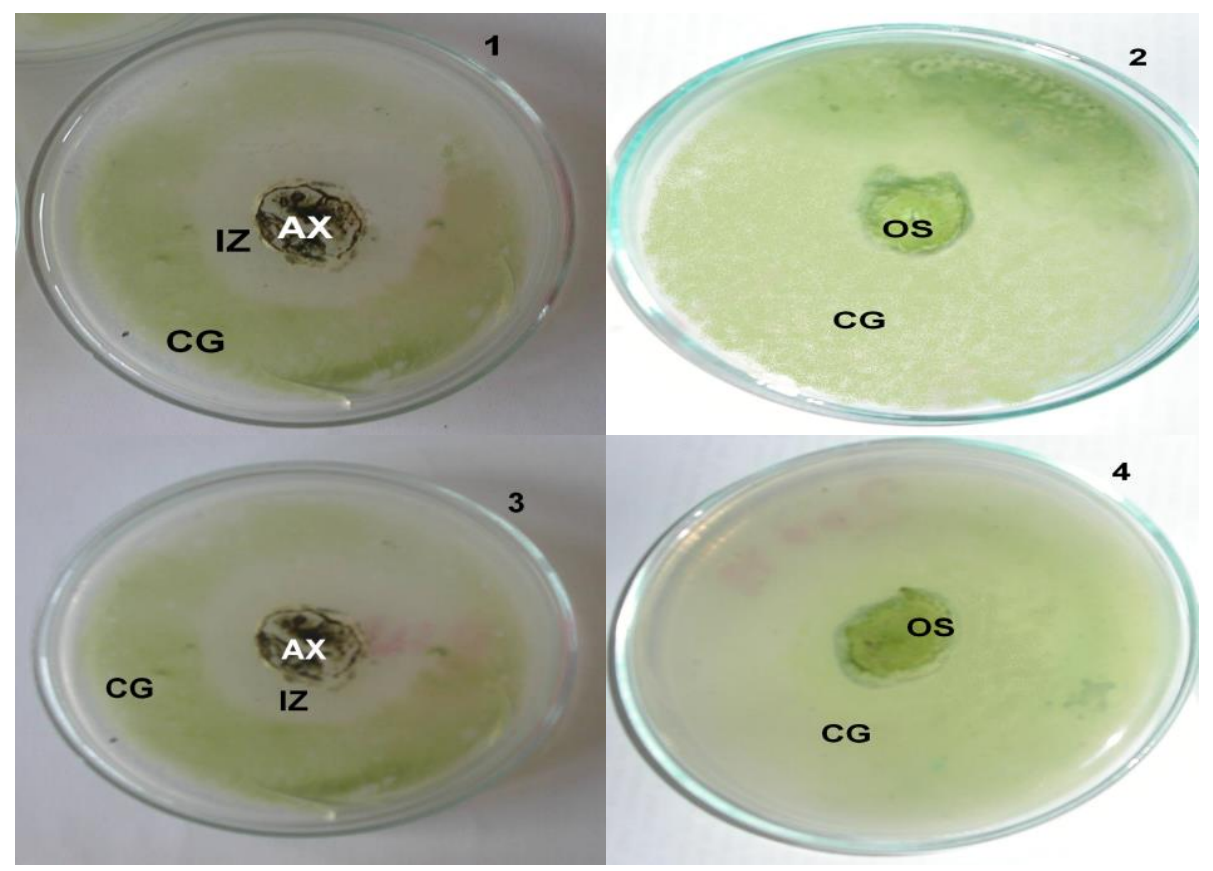

Photo (1): showing effect of $S$. acuminatus ethanolic crude extract on $C$. vulgaris growth. IZ=inhibition zone, $\mathrm{AX}=$ algal extract (ethanolic crude extract of $S$. acuminatus). $\quad \mathrm{CG}=C$. vulgaris growth.

Photo (2): Showing effect of organic solvent only on $C$. vulgaris growth using (Agarwell diffusion assay). $\mathrm{OS}=$ organic solvent (ethanol as control). $\mathrm{CG}=C$.vulgaris growth.

Photo (3): Showing effect of $S$. acuminatus methanolic crude extract on $C$. vulgaris growth. $\mathrm{IZ}=$ inhibition zone, $\mathrm{AX}=$ algal extract (methanolic crude extract of $S$. acuminatus). $\quad \mathrm{CG}=C$. vulgaris growth.

Photo (4): Showing effect of organic solvent only on $C$. vulgaris growth using (Agarwell diffusion assay). $\mathrm{OS}=$ organic solvent (methanol as control). $\mathrm{CG}=$ C.vulgaris growth.

Table (2): Allelopathic activity of (ethanolic and methanolic) crude extract of Scenedesmus acuminatus against Chlorella vulgaris growth by (paper-disc assay)

\begin{tabular}{|c|c|c|}
\hline $\begin{array}{c}\text { Quantity of algal extract } \\
(\mu \mathrm{l}) .\end{array}$ & \multicolumn{2}{|c|}{ Diameter of inhibition zone (mm) } \\
\cline { 2 - 3 } & Methanolic extract & Ethanolic extract \\
\hline 10 & $15.3 \pm 0.33$ & $17.6 \pm 2.18$ \\
\hline 20 & $16 \pm 1.52$ & $18 \pm 0.57$ \\
\hline 25 & $19 \pm 0.57$ & $22 \pm 1.57$ \\
\hline 30 & $20 \pm 1.57$ & $22.3 \pm 1.45$ \\
\hline 35 & $21.3 \pm 2.3$ & $23.3 \pm 0.88$ \\
\hline 40 & $22.6 \pm 2.8$ & $25.3 \pm 2.02$ \\
\hline
\end{tabular}

*There's no significant difference between ethanolic and methanolic extract at each treatment in the same raw. 


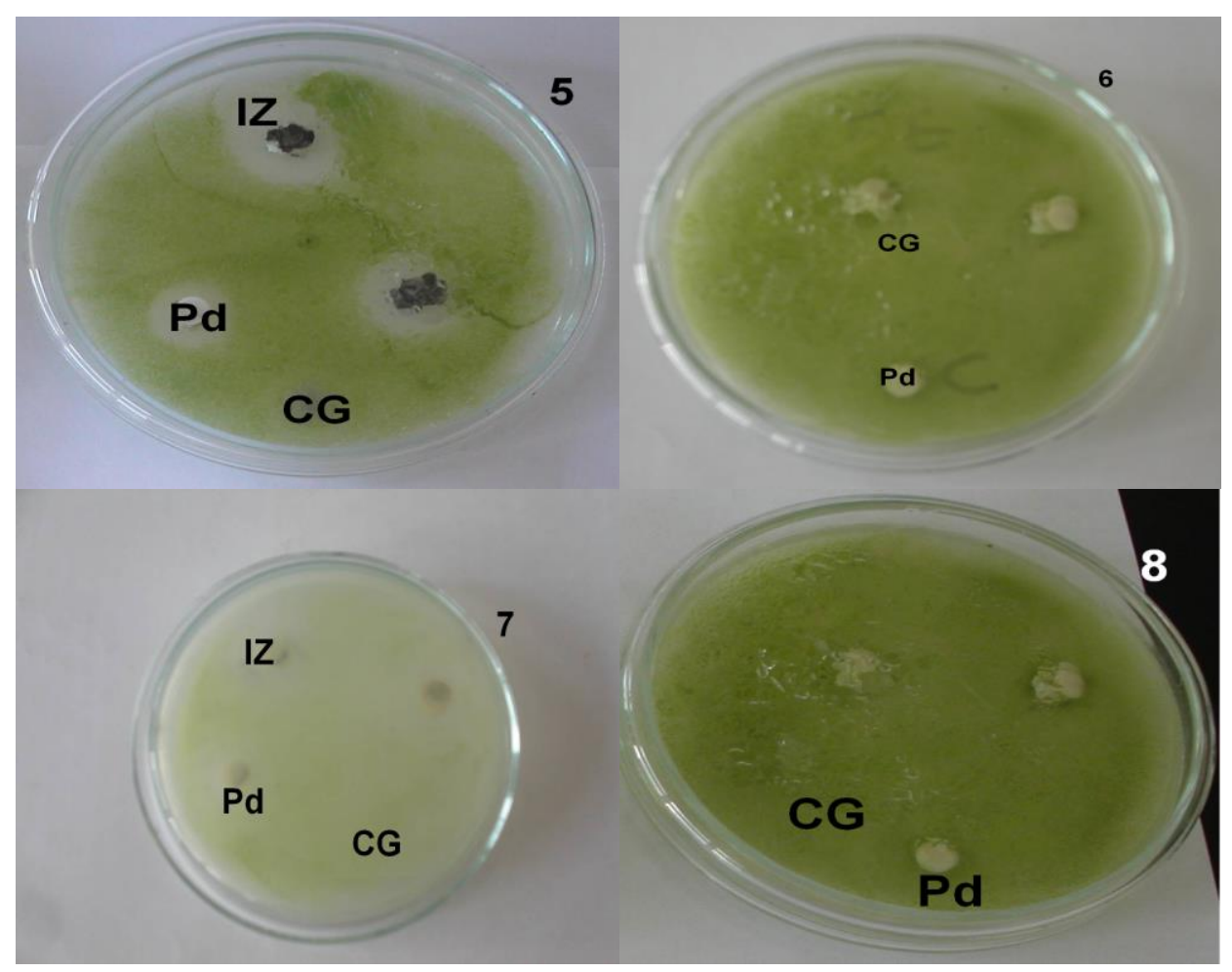

Photo (5): Showing effect of $S$. acuminatus ethanolic crude extract on $C$. vulgaris growth. $\mathbf{I Z}=$ inhibition zone, $\mathrm{Pd}=$ Paper disc impregnated with Scenedesmus ethanolic crude extract, $C G=C$.vulgaris growth.

Photo. (6): Showing effect of organic solvent only on $C$. vulgaris growth using (paperdisc assay). $\mathbf{P d}=$ paper disc impregenated with organic solvent only (ethanol as control). $\mathbf{C G}=C$.vulgaris growth.

Photo (7): Showing effect of $S$. acuminatus methanolic crude extract on $C$. vulgaris growth. IZ = inhibition zone. Pd = Paper disc impregnated with Scenedesmus methanolic crude extract. $\mathbf{C G}=C$. vulgaris growth.

Photo. (8): Showing effect of organic solvent only on $C$. vulgaris growth using (paperdisc assay). $\mathbf{P d}=$ paper disc impregenated with organic solvent only (methanol as control). CG = C.vulgaris growth.

\section{Discussion}

In particular, there has been a lot of interest in so-called allelopathic competition between two species, also due to their importance in many applications as for instance, in bio-remediation problems or laboratory biotechnological process. It is difficult for researchers to study allelopathic effects among aquatic organisms under natural conditions because factors such as nutrient and light competition, temperature and $\mathrm{pH}$ change can totally mask an allelopathic effect. So, it is necessary that attempts to identify allelopathic 
interactions among aquatic organisms should be conducted in a controlled system (Keating, 1977). So our experiments were run under stable and controlled laboratory conditions. Temperature and light and illuminating periodicity play an important role in production of harmful substances and harvested the causative organism at the exponential growth phase as (Egorov, 1985).

Our results in agreement with Jorgensen (1956) who recorded that Scenedesmus formed substances that inhibited the growth of Chlorella and that Chlorella filtrates stimulated Scenedesmus growth rate. Also results agreed with those recorded by Hulot et al. (2001) who stated that Chlorella growth was impeded by the presence of Scenedesmus, Chlorella seemed to suffer during its invasion in a medium already occupied by Scenedesmus, these result explained the release of substance inhibiting Chlorella growth by Scenedesmus. However, Grover (1991a, b) ran phosphorus-limited cultures where phosphorus was supplied at a constant concentration or with varying periodic pulses leading to non-steady continuous cultures to study competition between Chlorella and Scenedesmus. In all cases, Chlorella outcompeted Scenedesmus whatever the order of introduction. The absence of allelopathic effects during Grover's (1991a, b) experiments might depend on temperature, which is known to play an important role in the production of harmful substances. Grover's experiments were run at $12^{\circ} \mathrm{C}$ while Jorgensen's at $20^{\circ} \mathrm{C}$, Hulot's at $22^{\circ} \mathrm{C}$ and ours at $22 \pm 2^{\circ} \mathrm{C}$.

Our results conclude that the alcoholic (ethanolic or methanolic) crude extracts of $S$. acuminatus are able to inhibit growth of Chlorella. In agreement with our results, Souhaili et al. (2004) stated that ethanolic and methanolic extracts of marine algae had an inhibitory effect against Gram-positive and Gramnegative organisms and fungi. Results showed that well - diffusion assay is better than paper disc assay where inhibition zones were greater than that of paper-disc assay because the later has a limited saturation capacity.

More research needs to find out the chemical nature of inhibitor(s) substance (allelochemical, or algaecide).

\section{References:}

Bauer, A. W.; Kirby, W. M.; Sherris, J. C. and Turk, M. (1966). Antibiotic susceptibility by astandarized single disk method. Amer.J.Clin.Pathol., 45: 493-496.

Bischoff, H.W. and Bold, H.C. (1963). Phycological studies for some soil algae from Erchanted rocks and related algal species. Univ.Texas., 6318:32-36.

Desta, B. (2005). Antimicrobial activity of 63 medicinal plants. $J$. Ethnopharmacol., 100: 168-175.

Egorov, N.S. (1985). Antibiotics a scientific Approach. Mir Publishers, Moscow, P. 151.

Egyptian J. of Phycol. Vol. 12, 2011 
Gross, E.M. (2003). Allelopathy of aquatic autotrophs. Crit-Rev. Plant Sci., 22: 313-339.

Grover, J.P. (1991a). Algae grown in non-steady continuous culture: population dynamics and phosphorus uptake. Verh. Int. Verein. Limnol., 24: 26612664.

Grover, J.P. (1999b). Dynamics of competition among microalgae in variable environments: experimental tests of alternative models. Oikos, 62: 231243.

Jorgensen, E.G. (1956). Growth inhibiting substances formed by algae. Physiol. Plant, 9: 712-726.

Hulot, F.D.; Morin, P.J. and Loreau, M. (2001). Interactions between algae and the microbial loop in experimental microcosms. Oikos, 95: 231-238.

Keating, K. I. (1977). Allelopathic influence on blue-green bloom sequence in a eutrophic lake. Science, 196: 885-887.

Lampert, W. and Sommer, U. (1997). Limnology: The Ecology of Lakes and Streams. Oxford Univ. Press, New York.

Leflaive, J. and Ten-Hage, L. (2007). Algal and cyanobacterial secondary metabolites in freshwaters: acomparison of allelopathic compounds and toxins. Fresh W. Biol., 52: 199-214.

Legrand, C.; Rengefors, K.; Fistarol, G.O. and Graneli, E. (2003). Allelopathy in phytoplankton-biochemical, ecological, and evolutionary aspects. Phycologia, 42: 406-419.

Macias, F.A.; Oliva, R.M.; Simonet, A. M. and Galindo, J.C.G. (1998). What are allelochemicals? In: Olofsdotter, M. (Ed.), Allelopathy in Rice. IRRI Press, Manilla, Philippines.

Reitan, K. I.; Rainuzzo, J. R.; Oie, G. and Olsen, Y. (1997). A review on the nutritional effects of algae in marine fish larvae. Aqua., 155:207-221.

Statistical Analysis System (S.A.S) (2010). SAS Institute /STAT Guide for personal Computers, 6 th ed. Cary, NC.

Souhaili, Z.; Lagzouli, M.; Faid, M. and Fellat, Z. K. (2004). Inhibition of growth and mycotoxins formation in moulds by marine algae Cystoseira tamariscifolia. Afri. J. of Biot. , 3: 71-75. 


\title{
دراسة معملية للنشاط المضاد (الاليلوباثى) لمستخلص خام من طلب الكوريلا

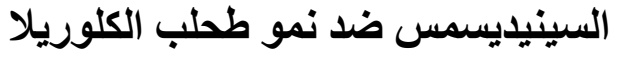

\author{
عايدة محمد ضوة"1 ، محمدرضا متولى 2 ، زينب عطية نجدى 1 ، ابراهيم محمد شاكر1، وامانى

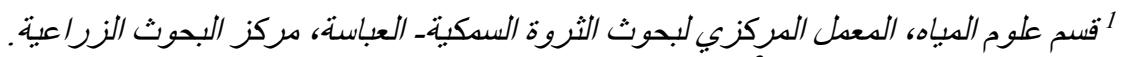 \\ 2 قسم النبات ، كلبة العلوم، جامعة بنها.
}

فيى هذا البحث تم عزل وتتقية نو عين من الطحالب الخضر اء و وهما سينيديسمس اكيومينيتس و كلوريلا

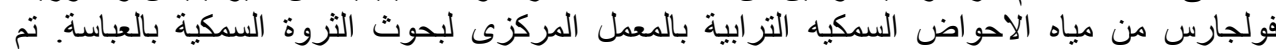

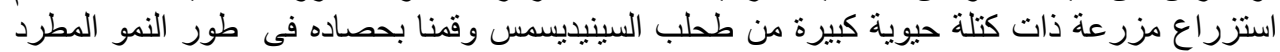

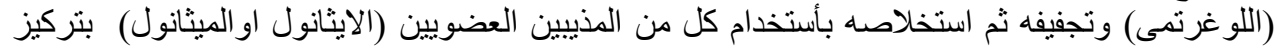

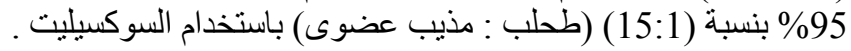

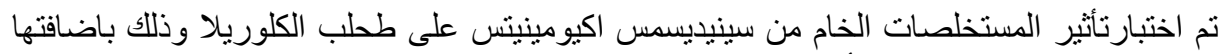

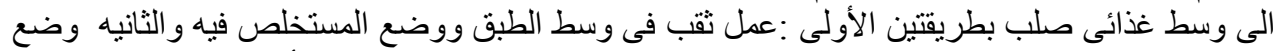

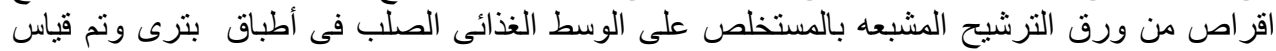
منطقة التثبيط حول القرص المشبع بالمسطرة واظهرت المبرت النتائج الاتى:

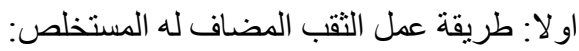

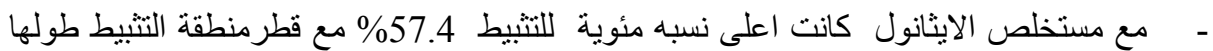

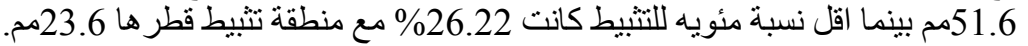

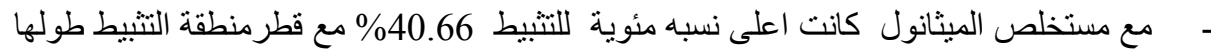

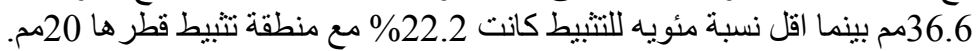
ثانيا: طريقة الاقر اص الورقيه المشبعة بالمستخلص:

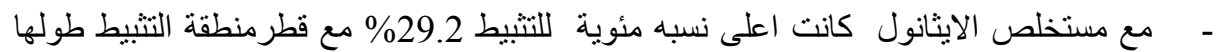

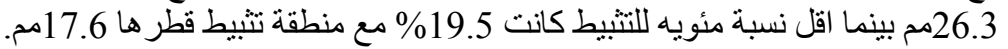

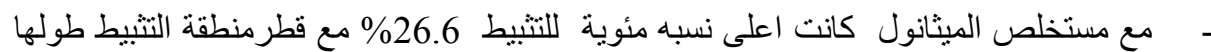

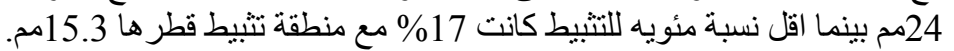

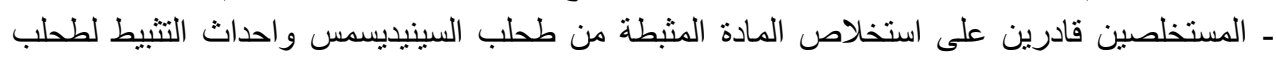

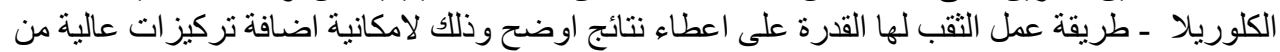

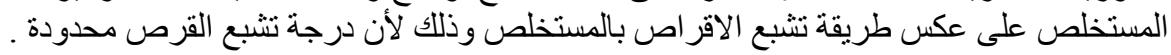

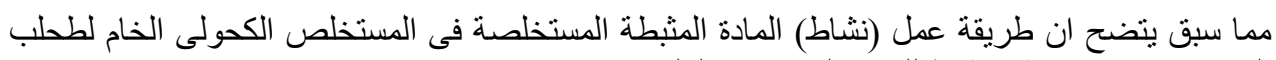
السينيديسمس قد احدثت تثبيط للكائن المستهدف الكلوريلا.

و استكمالا لهذه الدراسه فاننا سوف نقوم ان شاء الله بعمل عزل واستخلاص للمو اد الفعاله المسببه لتتبيط

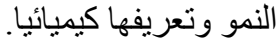

